\title{
From a Communist Heritage to an Unwanted Past The Case of Romania
}

\author{
Ricardo Parra, ${ }^{1}$ Jorge Ferraz ${ }^{2}$ \\ 1.M.A. Candidate, Tourism and Communication, Estoril Higher Institute for Tourism and Hotel Studies (Escola Superior de Hotelaria e Turismo \\ do Estoril), Avenida Condes de Barcelona, ㄲo 808, 2769-510 Estoril, Portugal \\ 2. Ph.D. in Sociology. Estoril Higher Institute for Tourism and Hotel Studies (Escola Superior de Hotelaria e Turismo do Estoril), Avenida Condes \\ de Barcelona, no 808, 2769-510 Estoril, Portugal \\ Correspondence to: Jorge Ferraz, Ph.D., Email: jorge.ferraz@eshte.pt; http://orcid.org/0000-0002-9805-727X \\ DOI: https://doi.org/10.15354/si.21.re076 \\ The authors declare no competing interest.
}

Communist ideologies and political regimes have had their specific models of tourism. These models reflect on the way former communist countries view tourism today. Despite the long communist period, Romania refuses to accept Communism as an integral part of its historical culture and society, being perceived as a dark period of its history. Several campaigns which were broadcasted as a way to show the cultural and natural beauty of the country, promote rural tourism and the ancient Romanian History, eluding themes and subjects related with that recent past. Even though there has been a growing touristic interest in Romania's communist heritage, the country's strategies express the difficulty in accepting Communism as part of the Romanian cultural identity and history. Thus, what communication strategies does Romania use to promote its culture, in order to avoid its communist heritage? What are the reasons behind the country's vehement silence about its past? This article aims to discuss how and why the country and its population promote specific tourist products as a way to avoid their communist legacy.

Keywords: Romania; Tourism; Communism; History; Ideology

Science Insights, 2021 July 27; Vol. 38, No. 1, pp.298-304.

() 2021 Insights Publisher. All rights reserved.

(c) (i) () Creative Commons Non Commercial CC BY-NC: This article is distributed under the terms of the Creative Commons Attribution-NonCommercial 4.0 License which permits non-commercial use, reproduction and distribution of the work without further permission provided the original work is attributed by the Insights Publisher.

Introduction

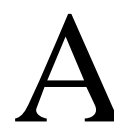
CROSS the 20th century, a political tide influenced by Karl Marx's and Lenin's communist doctrines, with its various developments and variations, mainly Stalinism, established itself in Europe, particularly in Eastern Europe (1). One of the countries that most affected by this political movement was Romania, which demonstrated also a great degree of nationalism. Only in 1989, through a violent revolution in Bucharest's largest square, could Romania depose Nicolae Ceaușescu's dictatorial regime (2).

Although this essay focuses on the communist period of Romania's history, it's important to notice that just before this long rule (from 1947 until 1989), the country left a nationalist fascist military dictatorship, led by Ion Antonescu, allied to and supported by the Nazi regime until 1944 (3). It was a period marked by a policy of ethnic persecution to Jews, Ukrainians, Hungarians, and even some Romanian ethnicities, ending in 1944 with the approach of the Soviet troops, the coup of August 23 that removed Antonescu from power, the subsequent declaration of war on Nazi Germany and the close end of World War II.

The nationalism associated with Romanian traditionalism and the proximity to Western values, present in the 19th and 20th century, gave place to a Stalinist Soviet internationalism marked by the proximity with the Soviet Union near the end of 
World War II (4). After 1947, the Romanian regime, in the hands of the Communist Party, through orders coming from Moscow, becomes a Stalinist regime, led by Gheorghe Gheorghiu-Dej, the first communist leader of Romania. After a few years of gradual diminution of the Slavic presence and the approach to the previous models of nationalism and traditionalism, Gheorghiu-Dej declared the primacy of Romania national sovereignty over the soviet bloc in 1964, despite maintaining a communist and Stalinist ruling Government form.

The rise to power of Nicolae Ceaușescu, in 1965, marked an important turning point in Romanian communism. This period of rule had two phases, quite different from one another (4). The first phase (1965-1971) marked by a great degree of openness to the outside world, making it easier for foreign tourists to travel more freely to the country. An important marker is 1971 , the year of the creation of the Ministry of Tourism. However, this freedom was only apparent, since the process of de-Stalinization was never noticed by the Romanian people (5). The second phase (1971-1989) focused on the closeness of the connection to the Western world and an increased degree of oppression: the bridge to the West was closed, with a focus on the control of Western tourist movements; power cutbacks and reductions in food distribution due to economic crisis, associated with the paying of all foreign debt; as well as the persecution of minorities (Jews, Gypsies, Hungarians, etc.) The dictatorial oppression ended in 1989 with a violent revolution in the main square of Bucharest, leading to the death of Ceaușescu at the hands of the communist members of his Party (6).

Having been a country with little openness to the outside world, in that period, tourism was one of the areas with less impact in Romanian economy, especially during the second phase of Ceauşescu's regime. However, in the first stage of Ceauşescu's communist rule, tourism coming to Romania had two main characteristics: due to easy obtainable visas and the improvement of infrastructures in the Black Sea coast, Romania was seen as a cheap tourist destination for Western tourists, also being a very popular destination among Central and Eastern European states looking for a sun and beach destination (5); Dracula tourism, which brought many tourists to the country during the first phase of Ceauşescu's rule in search of a mystic figure from Transylvania. This latter type of tourism is a highly controversial subject in Romania due to the image distortion of Vlad Tepes, an historical figure and a national hero, being still unapproved to this day (7). However, with the second phase in Ceaușescu's rule, the regime's most oppressive phase, marked by an isolationist policy, allied to food supply cutbacks, power outages and the increase in security control, the decline in the Romanian tourism industry was unavoidable (8). Romania's tourist decline contrasted itself with the growth of tourism in other socialist countries during the same period, such as Bulgaria and Hungary (5).

On the other hand, despite some organized trips to the Black Sea coast and educational visits to socialist monuments, spa tourism was the main type of tourism offered to Romanians, through a form of government paid vacations during both phases of the communist regime. Quite developed in Eastern countries back then, due to the great extension of thermal water, spa tourism was seen as a form of medical tourism (9). This difference in tourist offer for Romanian people and for Western tourists was regarded as a way to reinforce the comradery within the population and to minimize the ideological contamination from the West (10).

Since the fall of the communist dictatorship and the consequent democratic transition, the regime has focused its tourist offer in four main points (11): Bucharest (promotion of nightlife and cultural relations); Transylvania (connection between nature and historical background); Black Sea Coast (mixture of gastronomy and beach); Bukovina and Maramures monasteries (religious and architectural background). Through campaigns focusing on nation branding, Romania has tried to build a new image of itself, distancing from the communist framework which they intend to move away from $(12,13)$.

Unlike countries with a history of communism, such as Hungary and Czech Republic, Romania refuses to promote any sort of tourism related to that part of its past (14). Thus, knowing that Communism was one of the most impactful moments of its history, what communication strategies does Romania use to promote its culture, in order to avoid its communist heritage? This is the question that frames this essay since, despite the country's great cultural past, from enormous castles belonging to royalty, to the Romanian Carpathian Mountains, communist heritage has been the target of a large growth in touristic interests in Eastern Europe, as is the case of Romania (2).

\section{Methodology}

Although it is a rather controversial topic, as one of the political, economic, and social movements which most dominated the world in the 20th century (influencing mostly Eastern Europe and China), it is still a very current theme, for the influence exerted on those countries remains evident in their culture (15). In order to better understand the impact of this political movement in Romania's tourism, it is necessary to grasp the political, economic, and social context within which it fits.

The methodology applied is intensive qualitative research which was undertaken in order to develop a faithful academic paper. Thus, for the development of this essay, the author's technique was an analysis of different documents and scientific papers which could be relevant to the resolution of the question posed above $(16,17)$. To do so, the choice fell on the examination of theoretical papers, many of which elaborated by Romanian university students, specialized in the case study at hand, serving to deepen each branch of Romania's post-communist tourism. Given that documents are means of "expressing knowledge and experiences about a given social practice, it is also important to contextualize them and their authors in the societal framework and their problems" (18) (pp. 40)

Our research was focused on the following themes: tourism, politics and ideology, through its theoretical implication in the world $(10,18,19,20)$; the modern history of Romania, so as to understand its inherent nationalism and political background (3, $4,6)$; the concept of 'Communist Heritage' and its application in Romania, in order to better comprehend the communist regime's cultural legacy in the country $(8,21)$; the history of communist tourism in the Romanian post-communist age, so as to understand its phases and influence on the 21 st century Romania (5, 14); comparing the communist tourism in Hungary, in order to 
formulate different approaches to a similar ideological background $(1,21,22)$; types of tourism inherited from the communist age, constituting a better knowledge of what was offered in the socialist period and in present times $(7,9)$; nation branding strategies in current Romania, so as to comprehend the drifting from the communist past to other mediums of tourism offering $(12,13)$.

\section{Ideology and Tourism}

When speaking of ideology, one speaks of a system which serves as a map of orientation, interpretation and structuring of the world and of the practices of social actors, in a total or partial mode, leading to a notion of what is moral or immoral, fair and unfair. It has been in politics that ideology has obtained its higher degree of systematization in the practice of power and the conducting of the destiny of a society (19). Ideology is not specific to the political arena, but also a dimension of the cultural systems, scientific discourses and population's lifestyles, entering the cultural-ideological $(19,23)$. Tourism can thus be described as a social fact in its full scope, meaning that, not only does it include geographical characteristics, but also all social, political, economic, psychological, cultural and ideological factors which are fully inherent in it (20).

In the countries of Eastern Europe, tourism concentrated itself in specific areas permitted by the regime. This was due to an ideological control passed on to foreign tourists, not allowing a full demonstration of the reality in a certain socialist country, by then under the Stalinist political and ideological scope. This strategy of socialist development subordinated international tourism to the Stalinist economic and ideological model by: improvement in the infrastructures for the local population and not concerned with foreign tourists; promotion of international peace; socialist ideology being promoted over any other; tourist development having in mind the image being passed on to the outside world (10). All these objectives could only be accomplished through an enhanced ideological control by the government and by a structural organization of tourism economics and political goals.

\section{From Communism to Democracy: The Impact on Tourism in Romania}

Despite tourism's slight growth up until World War II, the fascist regime and the world conflict led to a halt in tourism development. After the rise to power of the Communist Party, tourism started to grow again. However, its growth and logics were highly influenced by the personality of leaders and the regime's communist ideology. Specially during Ceaușescu's leadership, tourism was again back on track, with the regime's first phase being very open to a specific tourism development characterized by: many investments in touristic infrastructures; openness to the Western world (Romania was, by this time, one of the most liberal countries of Eastern Europe under communist regimes); promotion of government paid vacations for the Romanian people (5). In 1971, the Ministry of Tourism was created, presenting a large stake of spa tourism, with a great demand by both foreigners and locals, attracted by travel packages offered at very affordable prices (9).

All changed in the early 70's with the passage to the second phase of Ceaușescu's rule, increasing the totalitarian nature of the regime. The control of tourist movement was implemented via mandatory daily reports from the tour guides. In the 80 s, the government applied severe austerity measures in order to pay off external debt: reduction in domestic consumption and investment; ration of energy supplies; export of almost all the agricultural products. Depletion of food and power outages, lack of investment funds for the tourism industry and for the improvement of its infrastructures, among other factors, led to a supply chain shortage in the accommodation establishments, drawing many tourists away from the country. These laws that intended to reduce dependence from Western Europe and pay off external debt, led Romania to isolating itself from the rest of the world (5).

During the regime's first phase, over $90 \%$ of international tourists came from Soviet Union-connected countries, on account of political and economic similarities and ties (5). There also seemed to be a constant fear regarding the ideological contamination by Westerners, so it was highly unlikely for the local population and Western tourists to be in the same spot (1). The contact between locals and foreigners was highly monitored: tourist experiences were mainly focused on group touristic packages, all of which were accompanied by an officially approved member of the Tourism Board of Romania. This was a constant in all of the communist Eastern Europe, with the supporting of tourism among socialist nations, which would enhance the sense of comradery between communist states. The arrival of Western tourists was considered a way of contamination of the socialist population through capitalist thinking, highly damaging to communist regimes (10).

After the fall of communism, with Romania's opening to the outside, a greater wave of tourists from various European countries started visiting the country, largely to explore its communist past (2). For Romanians, domestic tourism, the only permitted type of tourism given the regime restrictions, was changed by the fall of communism. Price liberalization, growing unemployment caused by Romania's economic transition, coupled with an improved array of countries to visit - often cheaper than vacationing in their own country — led many Romanians to stop practicing domestic tourism (5).

As in all of the socialist nations of Eastern Europe, their economy was a centrally planned one, meaning a total degree of nationalization of the country's properties and lands (1). This led to a hard time during the economic transition to a market economy, focusing itself on the privatization of properties as the measure chosen to restore the poor state in which the country was. Accommodations had belonged to the State during the entire regime and presented considerable shortcomings (5). There were no quality control parameters, structures needed requalification and the employees were in lack of formation in order to answer the demands of many tourists in search for destinations with higher hotel quality. Moreover, domestic tourism's falling brought several hotels to close their doors due to the lack of provisions. After the regime's collapse, in 1989, a big economic transition process was enacted, and many sectors were privatized and tourism one of the more important of those. In an early stage, the government established a plan aiming to try and keep the sector in Romanian hands (5): $70 \%$ of hotels could be 
sold to private investors but the other $30 \%$ belonged to each Romanian citizen who therefore could, through the acquisition of government-given vouchers, pay the value corresponding to the company they intended to buy. But the debile economy meant the people had no means to purchase property and so foreign private investors ended up buying the various estates. The entire sector was foreseen as privatized by 1996; however, only $22 \%$ was in private ownership (5).

The privatization by itself brought another question. After the fall of the communist regime in Romania, the new government tried to forget that considered dark past, creating tourist campaigns to lead tourists into exploring the country's ancient historical background and hidden Nature; but private investors saw in the communist history a market to explore (21)

\section{An Unwanted Past?}

According to some authors, to talk of 'communist heritage' is to talk of a cultural legacy composed of social and political elements which legitimize, in a way, the movement at hand. These are elements with a strong ideological load, whether statues or buildings, and may be distinguished first and foremost through their strong political load on tourism, for they may be used by various governments to idolatrize or condemn the movement, and through their controversial nature, accept or deny a country's cultural heritage (8). There are, therefore, two ways to approach the communist cultural past.

In Hungary, communism is seen as a part of its history, without any attempt to hide its past (21). Communist regime statues were relocated to Szoborpark, which serves as a permanent exhibition for that period of Hungarian history. The National History Museum dedicates a specific part of its infrastructure to communism's influence on the history of Hungary, instead of concealing it. Other countries share Hungary's values concerning their country's communist heritage. This has been the case in the Czech Republic and in Germany. This relatively moderate approach to this past is explained by two factors: on the one hand, these were countries in which the communist regimes were not too repressive or violent, and provided better life conditions to their citizens; on the other hand, communist heritage can be seen as a way to learn from past mistakes in order not to repeat them. The same approach is seen with dark tourism related to Nazi concentration camps throughout Poland and Germany (24).

In Romania, unlike Hungary, both the government and the population refuse to admit communism as historic and cultural past of the country. According to Porhib (2015), one example of this is the old Poporului House, built under Ceaușescu's rule with the purpose of becoming the greatest symbol of communist architecture in Europe. After the regime's fall, because of its dimension, demolition was rendered impossible, so it was used to harbor the Romanian Parliament. Many tourists visit the country to see it, but all guided tours omit the building's past and only mention the Romanian architectural beauty and its current roles (11). Other example is the Muzeul Național de Istorie a României, built in Romanian communism's heyday, functioning as a national propaganda source for foreign tourists, nowadays presenting exhibitions on Romania's history up until World War II and resuming after the Revolution of 1989, com- pletely omitting Ceaușescu's regime. Unlike State-managed cultural heritage, landmarks such as the Sighet Memorial, a political prison in Northern Romania, through private investment, was turned into a museum honoring communism's victims, including exhibitions in various cells, portraying the prisoner's hard living as well as communist Romania's daily life.

This difference between Hungary and Romania is largely owed to the communist regime's nature (8). While Hungary had a government where hunger and repression were not very noticeable, the Revolution being quite peaceful, the same did not happen in Romania (1). In the 80s, long stretches of hunger and repression led many Romanians to feel disgusted toward that dark period of their lives still to this day. The Revolution of 1989, excluding Albania's, was the most violent of all Eastern European communist regimes (14). In present day Bucharest, out of 39 touristic routes, only one presents elements of communism. The same approach is used in Bulgaria and Albania, those of which, throughout the period of democracy have led to a lack of restoration and preservation of communist heritage and, even in some cases, to their destruction (25).

Despite what we have seen, the newer generations seem to have a different approach regarding their attitude towards communist heritage. In a study conducted in three Romanian universities, new results surfaced (8). When asked about the communist tourist offering, college students were unanimously consensual: communism was an integral part of Romania's history and hiding it will not decrease the interest shown since the fall of the regime. Ceaușescu's communist regime should be contextualized in order for us to learn from past mistakes. With this new way of thinking by younger generations, it is clear that, in the future, a new light might be shown in the touristic approach to communist heritage in Romania.

\section{From Stoker to Thermal Resorts: Tourist High- lights during Ceaușescu's Regime}

Although Romanians declare that they do not identify with the country's communist past, two of the alternative types of tourism that reached their peak during this period remain to this day: Dracula Tourism and Spa Tourism.

Dracula Tourism caught the population and the government by surprise when, in the $60 \mathrm{~s}$, they saw many tourists arrive at their country from abroad in search of a character named Count Dracula (7). The first translation into Romanian of Bram Stoker's book only arrived in 1990, so the locals did not know how to answer this kind of demand, declaring it disrespectful towards Romanian culture. The character, loosely based in Vlad III's life, led the government to create touristic campaigns to educate tourists on the true historical figure. Despite this, foreign businesses (of American origin) kept promoting this type of tourism notwithstanding. Still to this day, the government's condemnation of Dracula Tourism is clear.

Spa Tourism in Romania, to the likeness of many Eastern Europe countries, underwent great development in the 20th century (9). The communist government saw in thermal springs a kind of alternative medical tourism much recommended by the physicians of the time. Having reached their prime in the communist age of Romania, large buildings were erected in the Carpathian zone in order to lodge tourists from various areas of 
Europe. Many tourists arrived during this period specifically to undergo this kind of tourism. They were mainly from fellow communist states. There was also a feeling of sumptuosity promoted through these ideology-filled resorts. These were built with the intention to show the richness of socialist government and to enhance the comradery between communist tourists, giving a sense of communion, much needed in order to legitimize the soviet empire.

From the perspective of domestic tourism, this was highly supported by a chain of state promoted social tourism - defined as the relations and phenomena in the field of tourism by citizens with weak economic conditions (26) - providing relatively cheap or free vacations for a specific period of time. This was the case of great part of the Romanian population, who used vouchers supplied by the government, in order to fulfill their yearly vacations.

The regime's downfall and the difficult economic transition led many establishments to close down, due to the lack of financial conditions and requalification. Nowadays, most social tourism is practiced by retired Romanians who choose to spend 18 days a year in a thermal resort of their own selection benefitting from government-given vouchers. Due to poor pensions this is the only type of tourism they can afford (9).

In what concerns other tourist's practices, it is important to notice that after 1990 there was an increasing desire, among Romanian tourists, to visit the side of Europe which they didn't had the opportunity to see until then. Despite this, the economic transition leading to the liberalization of prices and increasing unemployment in Romania prevented the citizen's touristic possibilities. Only with the 2007 integration of Romania in the European Union, leading to the easier circulation of Romanian citizens to Western Europe (ending visa requirements), the improvement of tourist and transport infrastructures, among other factors, there was an increase of outgoing and incoming tourist numbers in Romania (27). Domestically, due to the decrease of money available for spare time, culture and care, mainly because of recent economic crisis, Romanian tourists tend to spend the few days of vacation they have by the seaside, mountain and spa resorts. This reveals a trend in relaxing destinations among the working population, willing to spend their vacations surrounded by nature and calm (28).

\section{Post-Socialist Romanian Tourism Promotion and New Prospects}

After the fall of Ceaușescu's regime, Romania wanted to set itself apart from its communist past by restructuring its image, trying to attract tourists through specific efforts designed to show the country's best (11). Three campaigns were developed (broadcasted on the Internet or foreign television networks such as $\mathrm{CNN}$ ) with the intent to display new cultural narratives (13). To do so, nation branding strategies intended to reinvent Romania abroad were resorted to. Many of these campaigns were paramount in countries such as Bulgaria and Romania seeking to lure tourists to areas other than those of communist tourism (11).

Up to this day, government support and promotion of these campaigns shows an intention to specify certain points of attraction in Romania's territory. The four points of attraction are very distinct in their core (12). The first is Bucharest, through the promotion of the capital's nightlife and cultural background. Secondly, the Black Sea coast, with a degree of junction between beach, sun and gastronomy. Transylvania is the third destination promoted by the state, through the implementation of tourists in local rural activities and through the visit to historical places such as Bran Castle, the former residence of Vlad Tepes. Finally, Maramures' and Bukovina's monasteries enhance the search for Romanian's religious background and architectural marvels.

There seems to be policies of communist heritage avoidance through two measures: the focus in different tourist attractions in Romania's territory, especially the combination between rural, cultural and historical background; the erasure of communist history associated with the country's monuments (ex: Poporului House, Muzeul Național de Istorie a României, etc.) All of the previous campaigns exhibit tourism and leisure as communicational practices, yet they all lack a sense of cultural identity, expressing a manifest difficulty in managing other branches of the country's promotion, when most tourists intend to visit the communist heritage which the country rejects in itself (13). There is an increasing demand for Romanian communist tourism as part of the country's cultural identity by foreign tourists and a will to revisit a place whose reality was hidden from Westerners for so long. State backing could lead the promotion of communist tourist experiences to a larger capital injection into the Romanian economy, if only the population and the government would not refuse to accept communist tourism in the country instead of publicly condemning it (12).

But new trends could emerge. At the time of the study carried out by Rusu, Stanciugelu and Ţăranu (8), in which several young Romanian university students born after 1990 were presented with a questionnaire asking whether they were willing to accept communist heritage moving forward and developing it for tourism, the results were overwhelmingly unanimous: almost the entire sample showed availability to present the country's communist past whom many try to forget. Following the cultural transition model footsteps of countries such as Hungary and Czech Republic, we may say that the Romanian communist past is closer and closer to being opened and revealed.

\section{Conclusion}

To conclude this essay, it may be noticed that Romania suffers from an acute conflict of Identity vs. Economy (21). Paradoxically, the country asks for and needs money brought by tourism, but what could be a strong attraction for tourists is what (for ideological reasons and phenomena of identity construction and reconstruction), Romania intends to make invisible: its communist past. In fact, this is mirrored in the way the 1989 revolution happened: who organize it (members of the communist party and former dissidents, despite the popular initiative) and the controversy surrounding the rapid condemnation and firing of Ceaușescu and his wife.

As is the case with Eastern European countries similar to Romania, such as Bulgaria and Albania (precisely the poorest communist countries of Eastern Europe, following a Stalinist model of government and which, nowadays, face several corruption and democracy problems), there is also a sense of unwanted past vs. nostalgia (25). This sense of nostalgia comes 
from a period where there was a greater sense of community between the populations, mainly through their past working lives in the industry sector. Despite the hunger and the low incomes, these were times when most of the populations still hold dear to their memories. However, the unwanted past feeling seems to grow deeper than the nostalgia. This comes from the great repression and violence felt in the streets. Specially, in the case of Romania and Albania, who were governed, respectively, by Nicolae Ceauşescu and Enver Hoxha, the sense of repression was felt deeply during those last years of the communist regime, leaving a scar still quite open in the memories of the older generations. In the case of Romania, we must also bear in mind the scars and the troubled process of ending the extensive dictatorship. However, this is a problem mainly for older generations and people in positions of power, because new generations, born after the revolution and framed by a somehow different cultural and ideological framework, think otherwise.

\section{References}

1. Slocum SL, Klitsounova V. (Eds.) Tourism Development in Post-Soviet Nations: From Communism to Capitalism. ISBN: 978-3-030-30715-8, Palgrave Macmillan. 2020.

2. Light D. An unwanted past: Contemporary tourism and the heritage of communism in Romania. Int $\mathrm{J}$ Herit Stud 2000; 6(2):145-160. DOI: https://doi.org/10.1080/135272500404197

3. Deletant D. Ion Antonescu and the Holocaust in Romania. East Cent Eur 2012; 39:61-100.

4. Boia L. History and Myth in Romanian Consciousness. Central European University Press. 2001.

5. Light $D$, Dumbrăveanu $D$. Romanian tourism in the post-communist period. Ann Tour Res 1999; 26(4):898-927. DOI: https://doi.org/10.1016/S0160-7383(99)00033-X

6. Emmons AC. The violent revolution: Nationalism and the 1989 Romanian Revolution. Student Theses, Papers and Projects (History) 2016; 53:1-28. DOI: https://digitalcommons.wou.edu/his/53

7. Light $D$. Dracula tourism in Romania: Cultural identity and the state. Ann Tour Res 2007; 34(3):746-765.DOI: https://doi.org/10.1016/i.annals.2007.03.004

8. Stanciugelu S, Tăranu A, Rusu I. The communist cultural heritage in the social representations of a post-communist generation. Eur J Sci Theol 2013; 9(2):1-17

9. Erdelia G, Dincăa A, Gheorghilaşa A, Surugiub C. Romanian spa tourism: A communist paradigm in a post-communist era. J Stud Res Human Geog 2011; 5(2):41-56. DOI: https://doi.org/10.5719/hgeo.2011.52.41

10. Hall CM. Tourism and Politics: Policy, Power and Place. ISBN: 0471965472, 9780471965473, Wiley Publishers. 1994.

11. Kaneva N, Popescu D. National identity lite: Nation branding in post-communist Romania and Bulgaria. Int J Cult Stud 2011; 17:36-54.
12. Pătraşcu $C$. The politics of image and nation branding in post-communist countries: Branding policies in Romania. Pub Admin Region Stud 2014; 1(13):40-48.

13. Stoleriu O. Romania's Country Image in Tourism TV Commercials. 2nd International Multidisciplinary Scientific Conference on Social Sciences and Arts. lași, Romania: University Alexandru Ioan Cuza. 2015; pp867-pp874.

14. Pohrib $C$. The afterlives of communist things: Archiving feeling in post-communist Romania. Eur J Cult Stud 2015; 19(6):1-20. DOI: https://doi.org/10.1177\%2F1367549415597926

15. Hall DR. Stalinism and Tourism: A Study of Albania and North Korea. Ann Tour Res 1990; 17:36-54. DOI: https://doi.org/10.1016/0160-7383(90)90113-6

16. Eco U. Como se Faz Uma Tese em Ciências Humanas [How to Do a Thesis in Human Sciences]. Editorial Presença. 1998.

17. Flick U. An introduction to qualitative research, ISBN 978-1-84787-323-1, Sage. 2009.

18. Ferraz J, Serpa S. Tourism and cultural interaction: A paradoxical relationship. J Educ Soc Res 2021; 11(3):39-47. DOI: https://doi.org/10.36941/jesr-2021-0049

19. Ferraz J. Turismo e Ideologia: as Sociedades Mediterrânicas e o Papel Das Organizações Intergovernamentais [Tourism and Ideology: the Mediterranean Societies and the role of Intergovernamental Organizations] (PhD Thesis). Faculdade de Ciências Sociais e Humanas da Universidade Nova de Lisboa. 2009.

20. Ferraz J. Turismo e Globalização [Tourism and Globalization]. Planeamento e desenvolvimento turístico. Silva F, Umbelino J (Eds.), ISBN: 978-989-752-230-7, Lidel. 2017; pp79-92.

21. Light $D$. Gazing on communism: Heritage tourism and post-communist identities in Germany, Hungary and Romania. Tour Geog 2000; 2(2):157-176. DOI: 


\section{https://doi.org/10.1080/14616680050027879}

22. Pedersen SB, Noack C. Crossing the iron curtain: An introduction. Tourism and Travel during the Cold War: Negotiating Tourist Experiences across the Iron Curtain. Pedersen SB, Noack C (Eds.), ISBN: 9780367777272, Routledge. 2019; pp1-pp20.

23. Ferraz J. The Ideological Role of Intergovernmental Organizations in the Promotion of International Tourism. Controversies in tourism. Moufakkir O, Burns $\mathrm{P}$ (Eds.), ISBN-13: 978-1845938213, CABI. 2012; pp201-215.

24. Sharpley, R, Stone PR. The Darker Side of Travel: The Theory and Practice of Dark Tourism, ISBN: 978-1845412470, Channel View Publications. 2009.

25. lacono F, Këlliçi KL. Of pyramids and dictators:
Memory, work and the significance of communist heritage in post-socialist Albania. Online J Pub Archaeol 2015; 5:97-122. DOI: http://dx.doi.org/10.23914/ap.v5i0.66

26. Minnaert L, Maitland R, Miller G. Tourism and Social Policy: The Value of Social Tourism. Ann Tour Res 2009; 36(2):316-334. DOI:

https://doi.org/10.1016/j.annals.2009.01.002

27. Postelnicu C, Dabija D. Romanian Tourism: Past, Present and Future in the Context of Globalization. Ecoforum 2018; 7(1):1-13.

28. Mazilu M, Dumitrescu D, Marinescu R, Baltălungă A. New trends in Romanian tourism in 2018. J Tour Hospit 2018; 7(4):1-6. DOI: https://doi.org/10.4172/2167-0269.1000372

Received: May 25, $2021 \quad$ Revised: July 08, $2021 \quad$ Accepted: July 14, 2021 